\title{
Interpretacje
}

Luneta Rymkiewicza.

Mediumiczne auto/biografie

nowoczesnego klasycyzmu

Dorota Wojda

TEKSTY DRUGIE 2018, NR 6, S. 301-321

DOI: 10.18318/td.2018.6.21

łówną ideę nowoczesnego klasycyzmu tak sformuJłował Jarosław Marek Rymkiewicz we wstępie do Życie jest snem - imitacji dramatu Pedra Calderóna de la Barki:

Imitacja moja jest próbą odtworzenia oryginału La vida es sueño w innym języku. Odtworzenia, a nie powtórzenia. Nie chce bowiem zastępować oryginału i nie jest - nie może być - $\mathrm{z}$ oryginałem tożsama [...]. Czasownik imitari (imitor) należy do grupy słów określanych w gramatyce łacińskiej jako verba deponentia. Są to słowa [...] o formie biernej, a znaczeniu czynnym. Podobnie imitacja. Będąc, jak wszelka działalność przyswajająca, formą istnienia bierną, może być - jeśli zrodzi się z aktu porównania z umarłymi - znaczenie czynne. $(\dot{Z} S \text { 11-12 })^{1}$

1 Cytując teksty Rymkiewicza, używam skrótów: Cz - Człowiek z głowq jastrzębia, WŁ, Łódź 1960; D - Dwór nad Narwiq̨, w: Dwie komedie, Czytelnik, Warszawa 1980; J - Juliusz Słowacki pyta o godzinę, Czytel-
Dorota Wojda - dr

hab., adiunkt w Katedrze Teorii Literatury na Wydziale Polonistyki UJ. Zajmuje się problematyką mimesis, postkolonializmu i performatywności. Ostatnio opublikowała: Ironia w krytyce literackiej Bolesława Leśmiana, „Ruch Literacki” 2017. Kontakt: dorota. wojda@uj.edu.pl 
Z uwag tych wynika, że akt mimetyczny, w szczególności przekład, nie ma być wiernym naśladowaniem, ale kreacją odpowiednika różniącego się od oryginału, co umożliwia porównywanie i dynamikę form życia pochodzących z odrębnych czasów. Podobnie w Umschlagplatzu czytamy: „binokle Jakuba Wurzla lub Icyka Mandelbauma niech mi posłużą jako coś w rodzaju lunety, przez którą można oglądać - w stosownym pomniejszeniu lub powiększeniu - przeszłość albo przyszłość" (U 29). Rymkiewicz nie tylko akcentuje odmienne perspektywy interpretacyjne, wybierając mediumiczność, ale też podkreśla, że jego stanowisko nie jest odkryciem, lecz przetworzeniem w nowej dobie kulturowej dawnych wzorców artystycznych. Bliskie są mu zasady klasycznej estetyki oraz takie do nich nawiązania, w których docenia się rolę paradoksu, np. myśli z Lunety Arystotelesowskiej Emanuele Tesauro:

Apollina Praksytelesa naśladuje nie ten, kto przenosi jego posąg z ogrodu, w którym został ustawiony, do swego domu, ale ten, kto formuje według tych samych proporcji inną bryłę kamienia, tak by Praksyteles, widząc to, mógł ze zdumieniem powiedzieć: Nie jest to mój Apollo, a jednak jest on mój. Podać jednak należy, że wszelkie subtelne dzieło musi odznaczać się również pewną oryginalnością, bez której podziw, a wraz z nim powab i poklask maleją ${ }^{2}$.

W nowoczesnym klasycyzmie poety wyraźnie zaznaczają się sprzeczne sposoby czytania i pisania oraz ujmowania świata, podmiotowości i tekstu. Z jednej strony używa on figur wskazujących na pragnienie tożsamości: połączenia w całość tego „ja”, które jest opisywane i tego, które pisze; empirii z odpowiadającym jej znakiem, oryginału z odtworzeniem, fikcji z realnością.

nik, Warszawa 1982; K - Konwencje, WŁ, Łódź 1957; M - Metafizyka, Czytelnik, Warszawa 1963; MW - Mickiewicz czyli wszystko. Z Jarosławem Markiem Rymkiewiczem rozmawia Adam Poprawa, Open, Warszawa 1994; N - Niebiańskie bliźnięta. Komedia w trzech aktach według Calderona, "Dialog" 1973 nr 10; P-Pastuszek Chełmońskiego, Sic!, Warszawa 2013; PE - Porwanie Europy. Farsa w 2 aktach, "Dialog” 1971 nr 5; R - Rozmowy polskie latem roku 1983, Versus, Białystok 1991; $T$ - Thema regium, Czytelnik, Warszawa 1978; U - Umschlagplatz, Instytut Literacki, Paryż 1988; UM - Ulica Mandelsztama, Sic!, Warszawa 2012; ZN - Znakniejasny, baśń półżywa, PIW, Warszawa 1999; ZS - Zachód słońca w Milanówku, Sic!, Warszawa 2002; Ż - Żmut, Instytut Literacki, Paryż 1987; ŻS - P. Calderón de la Barca Życie jest snem, przeł., wstęp J.M. Rymkiewicz, PIW, Warszawa 1971.

2 E. Tesauro Luneta Arystotelesowska [w wersji łacińskiej]: Zasady ciętej i pomysłowej wymowy..., przeł. W. Nowicka, w: Źródła wiedzy teoretycznoliterackiej w dawnej Polsce. Średniowiecze - Renesans-Barok, wstęp, wyb. i oprac. M. Cytowska, T. Michałowska, PWN, Warszawa 1999, s. 457. 
Z drugiej strony Rymkiewicz wprowadza tropy poświadczające niemożność zintegrowania antynomicznych wymiarów. Pierwsza z tych praktyk pisarskich związana jest z powracającą, zwłaszcza w poezji, w zbiorach Anatomia, Co to jest drozd, Thema regium, Moje dzieło pośmiertne, wizją „budzenia zmarłych”, użyczania im przez twórcę głosu. Praktyka ta łączy się z imitowaniem konkretnych tekstów, a ponadto technik nowoczesnej literatury i nowoczesnego literaturoznawstwa. W dyskursie Rymkiewicza zaczynają być widoczne, podejmowane z ironią, środki autotematyzmu i anatomicznej metody strukturalnej, przy czym zyskują one kształt wielowymiarowego układu znaczeń.

W tej twórczości tekstowe „ja” zwraca na siebie uwagę jako realna postać autora: portretuje siebie w trakcie lektury, podczas pisania książek, mieszka na Filtrowej, a później w Milanówku, pracuje w Instytucie Badań Literackich, ceni Luisa Buñuela, ma rodzinę, która pochodzi z konkretnych stron (ich nazwy, nierzadko odnoszące się do miejsc akcji, ciągle powracają, stając się autorskimi sygnaturami). Lektura pisarstwa Rymkiewicza jako wyodrębnionego dyskursu przekonuje, że poeta zaprojektował je w formie całościowej autobiografii. Jej początek przedstawiony jest w Umschlagplatzu (dzięki relacjom opowiadającym o tym, co działo się 13 lipca w latach przełomu trzeciej i czwartej dekady ubiegłego wieku; Rymkiewicz urodził się 13 lipca 1935 roku) oraz w Kinderszenen (gdzie mowa o dzieciństwie poety), a której koniec ukazują opatrywane miesięczną i roczną datą wiersze z cyklu poświęconego ogrodowi w Milanówku. Czytelnik odnajdzie w tych granicach opowieść o niezliczonej liczbie rzeczy, osób i wydarzeń istotnych dla pisarza. $\mathrm{O}$ zegarku: „Mogę cię też porównać [...] do całego mojego życia. Mierzyłeś mój czas przez trzydzieści jeden lat, więc teraz powinienem opowiedzieć, jak żyłem przez te trzydzieści jeden lat” (RP 144-145), o dziadku: „Miał wtedy, w roku 1913, trzydzieści trzy lata. Był nauczycielem historii w gimnazjum im. Reja na Królewskiej” (RP131) czy o wnuczce Anielce: „Mrok smoków i pajęczyn wielki cień kasztana / Jeśli przez coś to przez to będziesz tu kochana" (Dla Anielki Rymkiewiczówny wyjeżdżającej do Francji - na pożegnanie, P 6).

W jednym ze swych wymiarów Rymkiewiczowski klasycyzm przyjmuje zatem formę dyskursu autobiograficznego. Zostaje w nim zawarty - używając formuły Philippe'a Lejeune'a - pakt, na mocy którego autor, narrator oraz pierwszoplanowy bohater są tą samą postacią․ Ma ona jednak szczególny status, gdyż stanowi „ja” prowokujące czytelnika do

3 Zob. P. Lejeune Wariacje na temat pewnego paktu. O autobiografii, red. R. Lubas-Bartoszyńska, przeł. W. Grajewski i in., Universitas, wyd. 2, Kraków 2007. 
zakwestionowania tego paktu, do odmowy zaufania komuś, kto stale narusza porozumienie: podaje sprzeczne informacje, zaciera granice pozoru i prawdy, konstruuje podmiotowość złożoną z różniących się od siebie przedstawień, zależną od warunków i metod pisania, wyłaniającą się ze strumienia narracji ${ }^{4}$. Pisarz prezentuje siebie jako osobę, której tożsamość ulega pod wpływem procesu twórczego metamorfozie, tym samym zaś autokreacji. Zmienia swój obraz na skutek poznawania znaczeń ujawnianych w praktyce lekturowej, przekształca się dzięki konfrontacji z postaciami Juliusza Słowackiego czy Bolesława Leśmiana.

Figury autobiografii Rymkiewicz łączy z figurami biografii - Aleksander Fredro portretowany jest podczas pisania, w kontekście współczesnej mu polityki i gospodarki, w gronie rodziny, jako człowiek uformowany przez swoją twórczość i jej interpretatora. W latach 8o. zacznie powstawać cykl mickiewiczowski, prezentujący obie postaci, romantycznego pisarza i Rymkiewicza, zgodnie z hermeneutycznymi zasadami przyswojenia. Komentując to przedsięwzięcie, współautor Mickiewicz czyli wszystko stwierdza, że teksty o Księciu Nowogródka „mają złożyć się na coś w rodzaju [...] totalnej biografii”, przy czym mają być „próbą odtworzenia” nie tyle historii poety, ile „całości losu, jego nieuchronności”. „Niekiedy wydaje mi się - mówi hermeneuta - że te książki równie dobrze mogłyby być książkami o kimś innym" (MW 27-29). Mickiewiczowi poświęca Rymkiewicz tak wiele miejsca z tego powodu, że jego dzieło jest mu najbliższe: ,jest to coś, na czym ja z racji mojego fachu [...] po prostu się znam. [...] Gdyby te informacje dotyczyły innego terytorium, to być może ten sam zamysł mógłby zostać wykonany właśnie na innym terytorium” (MW 29). Postanawiając spisać „totalną biografię" najlepiej sobie znanego twórcy, historyk może, niejako przy okazji, przypominać uznawane za mało ważne osoby i rzeczy:

„3 września. Za wymycie podłogi w dwóch stancjach u tegoż nauczyciela JPana Mickiewicza opłacono najętej kobiecie kopiejek czterdzieści

4 Ukształtowanie tego rodzaju podmiotowości zbliża Rymkiewicza do takich pisarzy jak Teodor Parnicki albo Władysław Lech Terlecki i takich badaczy jak Hayden White bądź Paul Ricœur (z Temps et récit). Autor Baketu tworzy „ja” o narracyjnej tożsamości, formułuje tezy dotyczące jej szczególnego statusu oraz interpretuje teksty, w tym studia historycznoliterackie jako autokreacje konstruowane w toku opowieści. Na temat związków pisarstwa Rymkiewicza z narratywizmem zob. K. Rutkowski Pisanie Mickiewicza albo esej o "ciele myślącym”, "Arcana" $1995 \mathrm{nr} 6$, s. 70-84; G. Marzec Hermeneuta i historia. Jarosław Marek Rymkiewicz w bakecie, Wydawnictwo IBL PAN, Warszawa 2012, s. 74-76. 
(40) [...]". [...] Dzięki temu zapisowi, a także dzięki temu, że uczestniczyła w jego życiu, że właśnie on, nie kto inny, stał tam w oknie, gdy myła podłogę - najęta kobieta ma wyraźnie określony stopień realności. $\left(\dot{Z}_{152}, 154\right)$

Tęsknota poety, zwrócona ku auto/biografii wolnej od poróżnienia między światem a tekstem, kieruje się ku takiemu porządkowi, w którym zniesiona zostaje granica między życiem a śmiercią; w którym zobrazowanie każdego najdrobniejszego szczegółu równoznaczne jest z jego wskrzeszeniem. Tęsknotę tę powierza autor Żmutu także swemu czytelnikowi. Zostaje on usytuowany, dzięki harmonizacji przedstawienia, w tej samej przestrzeni, co życie i dzieło Rymkiewicza oraz życie i dzieło Mickiewicza. W formie pytań, próśb i zagadek twórca pozostawia puste miejsca, które odbiorca mógłby wypełnić wątkiem własnego życia ${ }^{5}$. Rymkiewiczowskie pisarstwo okazuje się dyskursem oczekującym na proces lekturowej metamorfozy - zyskuje kształt, „ożywa”, dopiero wtedy, kiedy czytelnik „przyswoi” je sobie i kiedy sam stanie się obiektem jego „przyswojenia”. Zależność tę ilustruje scena z Rozmów polskich..., w której, jak często zresztą, Rymkiewicz korzysta z figury realizującej się antycypacji i, po wprowadzeniu dyskusji z czytelnikiem przyszłości, portretuje go w swetrze pana Mareczka, idącego w stronę mostku i pod niebem Suwalszczyzny roku 1983:

dlaczego ubrany jest w żółty sweter pana Mareczka, czyżby ten sweter nie został spruty? nie spłonął? ocalał? przetrwał tyle pożarów, powstań, ewakuacji? - i idzie szosą w kierunku mostku, jest rok 2033 albo 2053, i kimże on jest, o czym myśli idąc do mostku w moim żółtym swetrze i patrząc w niebo, które tam, nad mostkiem, jest fioletowe, nad polami błękitne, a nad puszczą czerwone z domieszką cynobru? (RP 94)

Auto/biografia Rymkiewicza ustanawia zatem dyskurs, który tworzy opowieść utożsamiającą autora, tekst, postać i czytelnika - autotematyzm scala tu podmiotową i przedmiotową sferę reprezentacji. Zespolenie tych sfer, wzajemnie się konstytuujących, równoznaczne jest z ukazaniem, że życie konkretnej osoby istnieje o tyle, o ile tworzy je tekst, a tekst - o tyle, o ile tworzy go życie konkretnej osoby. W konsekwencji poeta usiłuje pojednać

5 Jak pisze Anna Nasiłowska, poeta "flirtuje" z czytelniczką, choć "za chwilę powie: a ja już jestem gdzie indziej, przecież to nie było na serio!" (Flirt, „Res Publica” $1990 \mathrm{nr}$ 7/8, s. 107). 
przedstawione z przedstawieniem - znosi granicę, która znajduje się u podstaw kryzysu nowoczesności ${ }^{6}$.

Wymiar autobiograficzny zarysowuje się najwyraźniej w tekstach prozatorskich pisarza, ale jest obecny i w innych formach jego twórczości ${ }^{7}$. Wiersze z drugiego okresu Rymkiewiczowskiego pisarstwa kontynuują, a zarazem modyfikują linię wyznaczoną przez wczesne utwory: WWarszawie,Z pozótktych pokoleń albo Na urodziny poety J.M.R. (ur. 13 lipca 1935 r.), gdzie czytamy:

Chciałbym raz jeszcze wbiec po stromych

schodach, odwiedzić

Strych, odnaleźć ukryte między pożółkłymi

rocznikami gazet

Serce ośmioletniego chłopca

(WWarszawie, K21);

W szarym, podartym golfie, rocznik trzydziesty

W kieszeni źdźbła tytoniu i 45 groszy na

$$
\text { piąty, }
$$

tramwaj,

Czekałem natchniony

Na srebrny seans pamięci

(Z pożótktych pokoleń, K 22);

Przeżyłem, mówią inni, dwadzieścia pięć lat [...]

Urodzony przed chwilą, mam się ku końcowi.

Rozkaż, niech mnie pogrzebią na dnie moich wierszy

(Na urodziny poety J.M.R. (ur.13 lipca 1935 r.), M 17-18).

6 Powstanie procesualnej autobiografii, prezentowanej jako artefakt językowy, uznaje Ryszard Nycz za jeden z czynników odpowiadających za przemianę wyjściowego dla nowoczesności ujęcia literatury, a także ogólnokulturowego obrazu „ja”. Przyczyniła się ona do zatarcia idei, zgodnie z którą tekst tworzy formę zdepersonalizowaną, odizolowaną od autora. Dzięki temu możliwa stała się koncepcja narracyjnej tożsamości - uznanie „społecznej, kulturowej, a więc i językowo-dyskursywnej natury człowieka, współobecnego od początku w obszarach cielesnym i dyskursywnym" (Literatura nowoczesna: cztery dyskursy (tezy), „Teksty Drugie” $2002 \mathrm{nr}$ 4, s. 43).

7 Według Adama Poprawy takie liryki „pozwalają, by wraz z «ja» kreowanym wyraźnie zaznaczyło swoją obecność również [...] «ja» życiowe. Świat przedstawiony zostaje naznaczony autobiograficznym konkretem" (Kultura i egzystencja w poezji Jarosława Marka Rymkiewicza, Wydawnictwo UWr, Wrocław 1999, s. 98). 
Autoportrety te znajdą później dopełnienie w „Chodziliśmy razem z siostrą...", Kiedy się obudziłem, „Dlaczego sroka jest sroką nie kosem...”:

Masz czterdzieści dwa lata Możesz dożyć do

Siedemdziesiątki ale jeśli umrzesz

Jutro na zawał nie dowiesz się nigdy

Ile lat ten umarły mógłby jeszcze żyć

(„Dlaczego sroka jest sroką nie kosem...., TR 25).

W późnych zbiorach wierszy autobiograficzność stanie się podstawową zasadą poezji Rymkiewicza („I po co pióro kartkę czerni / Klasyk klasyczne wije wieńce / To chyba lepiej być tym w czerni / Tym romantycznym tam młodzieńcem" (Sentymentalny wierszykmarca,ZN9)), zasadą tak daleko posuniętą, że w tomie Zachód słońca w Milanówku realizującą się jako obraz śmierci autora:

Opowieść ta jest już skończona

Koty tańczyły wokół domu

Tango bolera charlestona

A ja umarłem po kryjomu

(Ogród w Milanówku - poezja brzóz i kotów, ZS 64).

Nurt biograficzny tworzą w poezji Rymkiewicza teksty o Czesławie Miłoszu („Poeta, do którego słów boję się przyznać. [...] Skromnie mądry, z ziarnkiem soli na wardze. [...] / Między Wschodem a Zachodem szukający" (Czesław Miłosz, K 28)), Zbigniewie Morsztynie (Zbigniew Morsztyn wraca $z$ Warszawy do Królewca (wiosna 1661 r.)), Słowackim („Gołąbku mój To jak jest Muza cię całuje / A ty do umywalki krwią czerwoną plujesz", Słowacki, TR 37), o Emanuelu Szafarczyku („Miał już prawie trzydziestkę, kiedy się zaczęło / I został naczelnikiem polskich sztyletników", Emanuel Szafarczyk, UM 19) oraz o wielu innych postaciach. W późnych lirykach Rymkiewicza biografia nadal odgrywa istotną rolę, przy czym na innych zasadach.

Również w poezji autor Baketu uruchamia i dokumentuje proces, w którym poznanie staje się kreacją, wprowadza podmiotowość o mediumicznym charakterze, konstytuującą się i konstytuowaną w procesie twórczym ${ }^{8}$. Kształ-

8 Jak zauważa Jacek Trznadel, „u Rymkiewicza - aktywizm, niepokój, ruch przenosi się w sam podmiot obserwujący, w strukturę jego wypowiedzi; nie zastygnięte, oszlifowane kryształy 
tując fikcyjne światy, pisarz niejako przywraca zmarłym życie, równocześnie zaś sam powołany zostaje do istnienia za pośrednictwem nie tyle własnej sztuki, ile dzięki relacji, jaką ustanawia między własnym tekstem a słowami uobecnianych w literaturze postaci. Zasadę tę wyraźnie obrazuje wiersz Exegi monumentum, gdzie stwarzają się wzajemnie głosy Mickiewicza i Rymkiewicza (wraz z nimi zaś głosy Horacego, innych kontynuatorów toposu oraz potencjalnych czytelników) ${ }^{9}$. W odzie Exegi munimentum aere perennius... romantyczny poeta odpowiadał Horacemu:

\section{Z Horacjusza}

Świeci się pomnik mój nad szklany Puław dach,

Przetrwa Kościuszki grób i Paców w Wilnie gmach,

Ni go łotr Wirtemberg bombami mocen zbić,

Ani świnia Austryjak niemiecką sztuką zryć.

Bo od Ponarskich gór i bliźnich Kowna wód

Szerzę się sławą mą aż po Prypeci bród.

Mnie w Nowogródku, mnie w Mińsku czytuje młodź

I nie leniwa jest przepisać wiele-kroć

W folwarkach łaskę mam u ochmistrzyni cór,

A w braku lepszych pism czyta mię nawet dwór!

Stąd mimo carskich gróźb, na złość strażnikom ceł,

Przemyca w Litwę Żyd tomiki moich dzieł.

Paryż 12 marca 1833. Wiersze natchnione wizytą Fran. Grzymaty ${ }^{10}$.

poetyckie oglądamy, lecz proces poetyckiego poznania. Jeśli zapożyczając swobodnie terminów [...] można by nazwać nadrealizm «behawioryzmem wewnętrznym», a awangardę «behawioryzmem zewnętrznym», to Rymkiewicz zdaje się porzucać oba trwałe punkty odniesienia. Także w samym procesie pisania" (Róże trzecie. Szkice o poezji współczesnej, PIW, Warszawa 1966, s. 203).

9 Zbigniew Dolecki wskazuje na polifonię i harmonizację zbioru Thema regium (skąd pochodzi Exegi monumentum). Jest on „rozpisany jakby na wiele głosów, lecz wszystkie one w końcu sumują się w jeden, podobnie jak wszystkie indywidualne śmierci zdają się łączyć w jeden strumień" ("Thema regium", „Kierunki" 1978 nr 39, s. 11). Marzena Woźniak-Łabieniec tak pisze o Exegi monumentum: „konstrukcja wiersza sugeruje silny związek i wzajemny wpływ między tymi, którzy - w różnych epokach - mienili się być poetami" (Klasyk i metafizyka. O poezji Jarosława Marka Rymkiewicza, Arcana, Kraków 2002, s. 75).

10 A. Mickiewicz Exegi munimentum aere perennius..., w: tegoż Dzieła, Wydanie Jubileuszowe, red. J. Krzyżanowski, t. 1: Wiersze, Czytelnik, Warszawa 1955, s. 379. 
Rymkiewicz tak odpowiada autorowi Pana Tadeusza:

Ten gaduła jąkała na trzynastu zgłoskach

Ten jakiż to jaki by ale łaska Boska

Ten któryż to któryż by którędyż który bądź

Ten skądeś to skądinąd skąd by skądże przybądź

Ten dokąd bądź dokądże aż za bród Prypeci

Pomniejszy pomny po mnie pomnik co się świeci

Ta śpiewka śpiewak śpiewność śpiewny i śpiewany

Exegi munimentum nad dach Puław szklany

Ten szklany szklanny szklony za szkłem szkli się szklisty

Te nasze cztery ściany a w nich iście isty

Ten błysk błysnęła albo błysła błyskawica

Dwukółką dwujęzyczny ten Żyd co przemyca

W Litwę Litwin li tylko Liwiusz przy Litwinie

Po litewsku po polsku język po łacinie

Ten wtórzący do wtóru wtóry i powtórny

Ta skóra na języku ten język podskórny

Ten czyjkolwiek czyj bądź by czym prędzej czymże to

To powietrze to które masz we krwi poeto

Ta krew z płuc na języku ta krew ci pokrewna

Ten słowik z krwi te deski z ojczystego drewna

Ten słowik ze słownika ten słownik słowiczy

Ten zmarły co na palcach zgłoski w trumnie liczy

(Exegimonumentum, TR 38).

Rymkiewicz odwołuje się do tekstu, w którym odnaleźć mógłby niezwykle bliską mu koncepcję twórczości poetyckiej: opartą na dwóch komplementarnych zasadach: pośredniczenia między kulturami, narodami i pisarzami, 
lecz także zabezpieczania się przed ich dominacją; utożsamiającą wiersz z pomnikiem szczególnej sławy - nie takiej jak u Horacego, ale pokrewnej chwale obwarowanego Słowa, stanowiącego schronienie dla indywidualnej i wspólnotowej tożsamości. Zmiana monumentum w munimentum oraz opatrzenie utworu dopiskiem „Paryż 12 marca 1833. Wiersze natchnione wizyta Fran. Grzymaty” oznaczają równoczesne ponowienie i przekształcenie Horacjańskiego wzorca, ponadto wprowadzają komizm oraz ironię, przy pomocy których mówiący w tekście poeta dystansuje się nie tylko wobec idei exegi monumentum, ale też wobec własnego dzieła i jego recepcji1". Ironia sprawia, że idea wiersza-pośrednika, wiersza-bastionu ulega trywializacji, wydaje się jedynie konceptem służącym sparodiowaniu stanowiska Horacego i postawy Franciszka Grzymały, czyli sztuki wznoszącej pomniki samej sobie. Z drugiej jednak strony ironia tworzy właśnie coś w rodzaju zapory (munimentum) przeciwko zagrożeniu autoafirmacją - artysta kpi z klasycznego poety, z siebie, ze swojego recenzenta i z innych czytelników, by nie wywyższać dzieła, które stało się już niejako tekstem użytkowym: przepisywanym „wiele-kroć” przez młodzież, zjednującym mieszkanki folwarków, dostępnym na carskim dworze, niczym towar przemycanym przez granicę zaboru. W czytanej serio odzie o świetlnej warowni można odnaleźć zamanifestowanie programu sformułowanego przez Mickiewicza w Epilogu do Pana Tadeusza, gdzie poezja utożsamiona zostaje z „księgami prostymi” w dłoniach litewskich wieśniaczek. Równocześnie zaś to tekst performatywny, w którym spełniają się zasady klasycznej ody jako działania i oddziaływania słowami ${ }^{12}$.

Nawiązanie relacji z Exegi munimentum aere perennius... okazuje się diagnozą, jaką postać zyskuje poezja - oddalając się od wzorów Horacego i Mickiewicza - w kulturze nowoczesnej. Świętą mowę "ogrodu z liter i słów” przeobraża Rymkiewicz w glosolalię, która buduje lingwistyczny poemat ${ }^{13}$. Mowę

Ironia wynika także stąd, że jako źródło natchnienia dopisek ukazuje pierwszego z recenzentów wileńskich Poezji, który po latach „bywał [...] częstym gościem w salonie Mickiewiczów i nieodmiennie wywoływał swą osobą śmiech zebranych [...] uprzykrzał się czytaniem swych poezji i nieustannymi pretensjami do literackiej wielkości" (D. Siwicka Grzymała Franciszek, w: J.M. Rymkiewicz i in. Mickiewicz. Encyklopedia, Horyzont, Warszawa 2001, s. 485).

Zdaniem Jamesa von Gelderna „oda stanowiła wydarzenie. Była skierowana do szczególnej publiczności na specjalną okazję, a jej zakorzenienie w konkretnej teraźniejszości warunkowało całość poetyki gatunku. [...] Dla pełnego zrozumienia ody trzeba uznać jej performatywną naturę i intencję" (The Ode as a Performative Genre, "Slavic Review”" 1991 vol. 50, no. 4, s. 928).

13 Ryszard Matuszewski pisał: „Rymkiewicz tworzy rodzaj wariacji poetyckiej na [...] temat Horacjańsko-Mickiewiczowski, posługując się przy tym konwencją stylistyczną upowszechnioną 
wiązaną zastępuje szeregami anakolutów i amfibologii („Ten czyjkolwiek czyj bądź by czym prędzej czymże to”), poliptotonów („Ten szklany szklanny szklony za szkłem szkli się szklisty”) czy paronomazji („Pomniejszy pomny po mnie pomnik"). Miara trzynastozgłoskowca stanowi podstawę, na której wspiera się, niby na postumencie, obraz nowoczesnego exegi monumentum, poezji czystej, zwróconej ku samej sobie, pełnej - jak w sytuacjach lirycznych Przybosia - światła i ruchu, powstającej w obecności czytelników, tożsamej - jak pragnęli tego awangardowi poeci - $\mathrm{z}$ wydarzeniem o realizującym się i wciąż niezrealizowanym kształcie.

Ani stylizowany w ten sposób wiersz-modlitwa, ani właściciel głosu, który woła: „Ten skądeś to skądinąd skąd by skądże przybądź”, nie zostają nazwani po imieniu. Bezimienny pozostaje także adresat błagalnej inkantacji - „ten”, "ta”, „to”, mówi o nim autor lirycznego zaklęcia. Twórca ów zapomina lub w ogóle nie wie, jakie cechy nosi przyzywana istota („jakiż to jaki”), kim jest („któryż to któryż”), gdzie się znajduje („skądeś to skądinąd”), dokąd może się udać („dokąd bądź dokądże”) i do kogo należy („czyjkolwiek czyj”). Równocześnie jednak wskazuje, że spełnia ona wszelkie bytowe możliwości - to ktoś „iście isty” (najprawdziwszy), , ,jaki by”, ,który bądź”, , ,skąd by”, ,dokąd bądź”, "czyjkolwiek". Niekiedy tylko przyzywający odzyskuje pamięć, kogo przywołuje, ale i wówczas nie potrafi określić dokładnie jego tożsamości. Zaklinanie sprowadzić ma poetę - oznajmia. Jednakże kim jest poeta? „Gadułą jąkałą na trzynastu zgłoskach”, ,zmarłym co na palcach zgłoski w trumnie liczy”? A może „łaską Boską"? Ale jeśli łaską, to czy daną przez Boga, czy godnym politowania beztalenciem? Łaską ,dosłowną” czy „frazeologiczną"? Rymkiewicz rzadko udziela odpowiedzi, a kiedy już to czyni, korzysta ze słów Exegi munimentum....

Pierwszy raz słowa te pojawiają się po pytaniu o miejsce, do którego przybyć ma poeta, i konkretyzują jednocześnie przestrzeń kolejnych objawień tajemniczej postaci („Ten dokąd bądź dokądże aż za bród Prypeci”). Zarysowuje się kontrast między mową nawołującego a językiem tego, kto mu odpowiada: pierwsza jest ledwie wysłowiona - dopiero się rodzi lub właśnie zamiera - druga tworzy zaś pełne, skrystalizowane frazy. Właśnie dzięki temu kontrastowi powstaje wrażenie, że w wierszu słychać dwa głosy; że występują

przez tzw. poetów-lingwistów [...], by w podtekście przemycić to, co jest najistotniejszym sensem utworu: myśl o przepływającym przez nas jak podskórny strumień krwi [...], strumieniu ojczystej mowy poetyckiej, łączącej poetów zmarłych z żywymi" (Dwa razy Jarosław Marek Rymkiewicz, w: tegożZ bliska. Szkice literackie, Wydawnictwo Literackie, Kraków 1981, s. 296). 
w nim dwie, wzajemnie się konstytuujące podmiotowości. Ze względu na przekaz intertekstualnego odniesienia (znaczenie aktualizowanego toposu) jedną z nich utożsamić można z Mickiewiczem, a drugą z Rymkiewiczem. Z takiej perspektywy Exegi monumentum okazuje się formą, w której zmarły poeta zostaje zawezwany tutaj i teraz niczym w obrzędzie Dziadów. W obrębie autorskiego dyskursu zaklęcie to może się spełnić dzięki klasycystycznemu prawu harmonizacji - tożsamości osoby i tekstu, życia i śmierci. Rymkiewicz zdoła uobecnić w liryce postać Mickiewicza, przyjmując, że wypowiedzenie (zapisanie) słów, które pozostawił po sobie autor Pana Tadeusza, równoznaczne jest z przywołaniem go do teraźniejszości. Romantyczny poeta zjawia się więc pod postacią swojej sztuki, w formie zdań recytowanych (przepisywanych) z mocą guślarskiego zaklęcia ${ }^{14}$.

Mickiewicza wzywa się, gdyż bez jego mowy współczesny poeta pozostałby "gadułą jąkałą na trzynastu zgłoskach", a jego wiersz byłby tylko pięknym przedmiotem konceptualnej kreacji. Autor zyskuje zdolność wysławiania się w tych miejscach, w których glosolalię - jedyny głos, jaki potrafi z siebie wydobyć - przerywa dykcja Exegi munimentum... W tej lekturze nie tylko określenia poety z pierwszego dystychu odnoszą się do klasycysty, ale też słowa: „Ten zmarły co na palcach zgłoski w trumnie liczy”. Oznacza to, że poza aktem repetycji nie ma Rymkiewicza-poety - jest wierszokleta „z Bożej łaski”. Przyzywając twórcę pomnika, co wznosi się „nad szklany Puław dach”, przyzywa on siebie. Spełnienie zaklęcia sprawia, że bezładna gadanina przeistacza się w poezję; że słowa powracają do swych znaczeń - fraza „szklany szklanny szklony za szkłem szkli się szklisty” przestaje być już tylko czystym brzmieniem poliptotonu, bo zyskuje także formę znaczącego opisu rzeczywistości.

Rzeczywistością tą jest bujność świata odzwierciedlona przez bogactwo języka, które pomnożył twórca Pana Tadeusza. Pojawiające się w Exegi munimentum wizje świetlistego pomnika, przekraczania brodu na Prypeci, Żyda-przemytnika klasycysta zmienia w obrazy mediumicznej poezji zbliżającej pisarzy

14 W rozmowie z Adamem Poprawą, zatytułowanej Ja, Adam Mickiewicz, jestem upiorem, poeta rozwija myśl bliską Exegi monumentum i w ogóle koncepcji własnego pisarstwa: „jak istnienie Gustawa i [...] pasterki jest włączone w sferę obrzędową, tak i istnienie tego, kto czyta, znajduje się w sferze obrzędowej. Dzięki temu, że autor, czyli Adam Mickiewicz, pełni tam rolę [...] guślarza" (MW 94). Odnosząc się do tych słów, Marzena Woźniak-Łabieniec odnotowuje: "interpretacja II części Dziadów brzmi jak komentarz do programu klasycyzmu” (Klasyk i metafizyka..., s. 34), a Jan Kott pisze: "Żmut, jaka to Forma? «...szukaj umarłych pośród nas żywych». Żmut - to są Dziady. I w tym największe odkrycie Rymkiewicza” (Żmut - jaka to forma?, "Zeszyty Literackie" 1987 nr 20, s. 142). 
różnych czasów (Horacy - Mickiewicz - Rymkiewicz), języki różnych kultur („dwujęzyczny ten Żyd co przemyca / W Litwę [...] Liwiusz przy Litwinie / Po litewsku po polsku język po łacinie"), a także rozdzielone pierwiastki spójnej niegdyś całości przedstawienia i przedstawionego. Tym samym autor Thema regium nie tylko modyfikuje tradycyjną zasadę "powtórności” (imitacji) ${ }^{15}$. Bycia „wtórym Horacjuszem" nie łączy on ze zdobyciem pośmiertnej sławy ani też nie ogranicza do stworzenia dzieła wspólnotowego. Wizję słowa, które ocala zbiorowość, bo przepisywane jest „wiele-kroć” i mieszka w przestrzeni ojczystego domu, przeobraża Rymkiewicz w nowoczesną ideę mediumiczności, zespolenia osoby i tekstu, tego co cielesne i tego co językowe („Ten wtórzący do wtóru wtóry i powtórny / Ta skóra na języku ten język podskórny"). Auto/biograficzność Exegi monumentum uwidacznia się nie tyle przez odniesienia do faktów z życia pisarzy, ile przez odesłania do tekstów, które o tych faktach mówią. Wiersz wymaga, by odczytywać go przez pryzmat ody Mickiewicza, a w niej znajdują się związane z poetą nazwy topograficzne, aluzje do rzeczywistej recepcji jego dzieła i anegdotyczny dopisek wyjaśniający okoliczności powstania tej szczególnej trawestacji. Ponadto ukazanie, że tekst przyciąga ku sobie dwa pisarskie światy, a także nadrzędna rama Thema regium, zbioru o auto/biograficznym charakterze, sugerują odczytanie wiersza w kontekście innych utworów klasycysty, w konsekwencji zaś - potraktowanie go jako opowieści o życiu (i śmierci) realnych poetów.

Figury konstytutywne dla tego rodzaju narracji występują także w dramatach Rymkiewicza, obejmujących calderonowskie imitacje. Ślady wskazujące na autora czy kogoś innego jako na rzeczywiste pozatekstowe osoby nie są w nich tak wyraziste, jak w „romansach naukowych”, ale mają istotne znacze$n^{1 e^{16}}$. W Niebiańskich bliźniętach Gila, kiedy pragnie porzucić swą rolę i zwraca

15 Przywołując Rymkiewiczowskie pojęcie imitacji, Agnieszka Fulińska zwraca uwagę, że „przekład, zwłaszcza poetycki, bywa obecnie postrzegany jako uwikłany w relacje z szerszymi ideami dotyczącymi powiązań międzytekstowych, w których istotną rolę odgrywa podmiotowość tłumacza, imitatora czy też współzawodnika oryginalnego tekstu i jego autora, a do głosu dochodzi także rozdarcie pomiędzy podobieństwem i odmiennością, odtwarzaniem i tworzeniem" (Naśladowanie i twórczość. Renesansowe teorie imitacji, emulacji i przekładu, Leopoldinum, Wrocław 2000, s. 5-6).

Charakteryzując nowoczesny dramat, Anna Krajewska zauważa: „w świat utworu wkroczyła osoba twórcy. [...] To właśnie wejście autora w obszar sztuki sceny rozpoczęło proces filiacji z liryką i epiką. Inwazja «ja» lirycznego i «ja» epickiego była możliwa dzięki osobie sprawcy. Ośrodkiem nowoczesnego dramatu stał się bowiem autor i jego biografia" (Osoba w dramacie i teatr osobny, w: Osoba w literaturze i komunikacji literackiej, red. E. Balcerzan, W. Bolecki, Wydawnictwo IBL PAN, Warszawa 2000, s. 257). 
się do nieba o zmianę przedustawnych wyroków, to właśnie autorowi komedii daje do zrozumienia, że byłby osłem, gdyby nie odstąpił od powziętego planu:

$\quad$ byłby osłem
kto by wolał przez dzień cały
nosić wodę, rąbać drzewo
prać koszulę lub komedie
imitować z hiszpańskiego
mogąc zostać jak ja zbójcą
więc zostanę zbójcą niebo

(N35).

Zawoalowanie auto/biograficznych odwołań wynika w dramatach m.in. ze specyfiki tego rodzaju literackiego. Stosując się do tradycyjnych konwencji wedle których nadrzędna podmiotowość pozostaje w dramacie nieobecna ${ }^{17}$ - Rymkiewicz nie wprowadza na scenę twórcy jako widzialnej, działającej persony, ale wybiera bardziej wyrafinowany sposób na oznaczenie swego istnienia. Kształtuje swoje sztuki tak, by autorskie „ja” stanowiło projekcję postaci odgrywającej bohatera, rolę i osobę aktora. Bohaterowie przedstawiani są jako marionetki wykonane i poruszane przez kogoś, kto istnieje poza rzeczywistością dramatu (teatru), przy czym noszą na sobie - jak „niebiańskie bliźnięta" - znamię, które jest śladem ich stwórcy. Równocześnie jednak uznają siebie za kreatorów dramatu, swych ról i swego autora:

lecz z kim mówię kogo proszę

przed kim padam na kolana

przed kim czołgam się na deskach

gdy to ja cię moja farso

ja twój Kicio teraz piszę

$$
\text { (PE 45-46). }
$$

17 Anne Ubersfeld pisze, że w każdym dramacie występuje „ja-skryptor", "wypowiadacz", instancja wywołująca wrażenie swej nieobecności, a zarazem odpowiedzialna za istnienie "kontraktu teatralnego": „Dyskurs teatralny należy do podmiotu «skryptora», ale jest dyskursem podmiotu tracącego natychmiast swoje «ja», który neguje się jako taki i który się afirmuje jako mówiący głosem innej osoby, wielu innych" (Czytanie teatru I, przeł. ). Żurowska, PWN, Warszawa 2002, s. 188). 
Podobnie jak w innych formach Rymkiewiczowskiego pisarstwa, w dramacie występuje relacja dwustronnego oddziaływania: tekst, czyli projekt ról scenicznych, zostaje ukazany jako skonstruowany przez realnego autora i konstruujący jego osobę. Oprócz postaci także aktorzy i reżyser wnosić mieli ślady rzeczywistych autobiografii - poeta zostawiał w dramatach miejsca, które oczekiwały na wypełnienie jednostkowym doświadczeniem. Dlatego zależało mu na współpracy z teatrem - chciał wiedzieć, kto będzie inscenizatorem spektaklu i kto w nim zagra. Prezentując koncepcję tworzenia nowoczesnego dramatu, apelował: „Niech będzie napisany dla konkretnego teatru, niech jego autor w okresie swej pracy będzie członkiem zespołu teatralnego, dla którego pisze"18. Rymkiewicz sądził, że taki dramat będzie z n a c z ą c y - istotny nie tylko w planie kulturowej diagnozy, ale też w sferze pozascenicznej egzystencji zaangażowanych w przedstawienie osób. Od aktora oczekiwał kreacji eksponującej sztuczność, autotelicznej, a zarazem wywiedzionej z własnej biografii ${ }^{19}$.

Twórca Niewidzialnej kochanki... poddawał bohaterom słowa wskazujące na osobę dramatopisarza - zwykle w calderonowskich imitacjach przynajmniej jedna postać to porte-parole Rymkiewicza. W Królu Mięsopuście jest nią abdykujący Król - „słowik-poeta”,, czytelnik Kanta”, który „,czuje się ostatnim strażnikiem «wartości duchowych»”, „współczesny klerk bezradny i przerażony"20. Król Mięsopust (1970) nie zawiera jeszcze odniesień do biografii pisarza, już jednak w Porwaniu Europy (1971) informacje na temat bohaterów pokrywają się z faktami z życia poety, np. Kensington ma tę samą datę urodzin: „ja w trzydziestym piątym panno / urodzony tuż przed wojną” (PE 28). Najwięcej sygnałów autobiograficznych umieścił Rymkiewicz w ostatnim ze swoich dramatów, Dworze nad Narwia (1979), rozdzielając je między różne postaci. Tadzio opowiada Jenerałowi: „dziadek był dyrektorem liceum, a może gimnazjum w Pułtusku. A kiedy na starość osiadł na wsi, uczył czytać i pisać dzieci z czworaków" (D 221). W Wielkim księciu..., Rozmowach polskich... tak

18 J.M. Rymkiewicz Wieńce... Na zakończenie sezonu teatralnego, „Odgłosy” 1958 nr 16, s. 5.

19 Jeśli wierzyć recenzentom sztuki Życie jest snem w reżyserii Ludwika Renégo (1969), taką kreację stworzył, występujący w roli Sigismunda, Gustaw Holoubek: „kiedy dochodzi do ostatniej [...] fazy swego dramatu, gra już w istocie siebie [...]. Myślę, że jest to jedno z największych osiągnięć aktorskich w ostatnich latach" (L. Jabłonkówna Wehikuł czasu Gustawa Holoubka, "Teatr" $1969 \mathrm{nr}$ 14, s. 6); „Łączy on oddzielne partie, wcielenia, «role» bohatera. Odgrywa je i pokazuje, że odgrywa. To on głównie, parodiując teatr, zarazem teatr stwarza" (A. Jackiewicz Teatr Calderona ,"Film" $1969 \mathrm{nr}$ 46, s. 10). 
przedstawia poeta własnego dziadka. Sama Narew często powraca w Rymkiewiczowskim pisarstwie jako motyw uspójniający autorski dyskurs: „Nad falą Narwi ciała smagłe / Jak świeczki dziecinnego tortu / Zagasił wiatr zapomnień nagły”, Do emigranta, $C z$ 14); „I czarna Narew spała między olszynami / Jak w moich snach dziecięcych jak pomiędzy snami" (Wiersz dla Ignacego Rymkiewicza (na jego pierwsze urodziny), P 47). W komedii o zamieszkujących dwór nad Narwią upiorach mediumiczność auto/biografii polega na tym, że poeta miesza fakty z własnego życia i z dziejów swojej rodziny z elementami życiorysów innych pisarzy i osobistości historycznych, przypisując je postaciom fikcyjnym. Tacy hybrydyczni bohaterowie stają się, jak w Umschlagplatzu, lunetą Rymkiewicza - pośrednikami, dzięki którym zbliżają się do siebie różne czasy i realia życiowe, bronione w parabazie przez podającego się za twórcę sztuki wampira:

w trybie przedmowy, którą przed tą komedią myślałem położyć, ale sądzę, że i tu, w trzecim akcie, można by ją zamieścić, [...] kilka słów powiem. [...] więc żeby mi reżyser nie machał, proszę, ołówkiem, wykreślając to, co w tej komedii może wydać się nieistotne, a co dla mnie bardzo istotne: myślę o wszystkich realiach życia - choćby o tych serach, to z kminkiem, to z ziołami, [...] o tej świeczce [...], o tym derkaczu nad Narwią. (D 232-233)

Dwór nad Narwia pochodzi z okresu, w którym wyraźne jest już przejście od klasycystycznej poetyki kultury do hermeneutyki istnienia, obejmującej serię wierszy na temat ogrodu w Milanówku czy encyklopedie poświęcone Słowackiemu i Leśmianowi, gdzie odnotowane są wszelkie szczegóły zwykłej egzystencji.W tych auto/biografiach znaczenie mają nie tylko fakty tradycyjnie uznawane za istotne - narodziny, napisanie dzieła, śmierć - ale również drobiazgi z haseł Kapelusze Leśmiana, Fiołki Mathilde czy Klucz od komody, jakie docenia się w mikrohistorycznym nurcie współczesnej biografistyki ${ }^{21}$. Równolegle zmienia się stosunek Rymkiewicza do tłumaczenia - stwierdza teraz, że właściwie nie jest ono możliwe:

21 Zob. J. Lepore Historians Who Love too Much: Reflections on Microhistory and Biography, "The Journal of American History" 2001 vol. 88, s. 129-144; S. Loriga Le Petit x. De la biographie à I'histoire, Editions du Seuil, Paris 2010; Theoretical Discussions of Biography: Approaches from History, Microhistory, and Life Writing, ed. by H. Renders, B. de Haan, Brill, Leiden-Boston 2014; S.G. Magnússon The live is never over: biography as a microhistorical approach, w: The Biographical Turn: Lives in History, ed. by H. Renders, B. de Haan, J. Harmsma, Routledge, Abingdon-New York 2017, s. 42-52. 
ponawiamy - możemy ponawiać tylko te wzory, które odziedziczyliśmy razem z własnym - więc ojczystym językiem. Inne języki są nam nieznane, choćbyśmy je znali. Tłumaczenie wierszy na przykład - sam to kiedyś uprawiałem - dzisiaj uważam za rzecz niemożliwą. Te wiersze, które ma się ochotę przełożyć, należy po prostu jeszcze raz po polsku pisać22.

"Inne języki są nam nieznane, choćbyśmy je znali", pisze Rymkiewicz, kiedy zmienia koncepcję klasycyzmu, ale już wcześniej - w ramach dotychczasowej poetyki - zaznacza się niemożność utożsamienia podmiotowych i przedmiotowych instancji. Poeta uznaje, że przezwyciężenia nowoczesnego dualizmu nie dokona się na zasadzie prostej negacji; że figury przyswojenia i poróżnienia muszą współistnieć. Rymkiewicz nie chce „przenosić - by powtórzyć słowa Emanuele Tesauro - posągu z ogrodu, w którym został ustawiony, do swego domu”, ale pragnie „formować według tych samych proporcji inną bryłę kamienia". Polega to na zrywaniu więzi między elementami konstytuującymi autorski dyskurs: pisarzem, jego książką, występującymi w niej postaciami, czytelnikiem. Z tym porządkiem łączy się wizerunek zmarłych, którzy nie mogą zostać w żaden sposób wskrzeszeni przez poetę i ukazywanie zagłady, jaka staje się ich udziałem w literaturze. Dzięki tej zmianie imitacja - jak czytamy we wstępie do Życie jest snem - pozostając „formą istnienia bierną", "przyswajającą”, uzyskuje „znaczenie czynne”. Gra między przyswojeniem i poróżnieniem jednak dobiegła kresu. Od lat 80. zaczął kształtować się w pisarstwie Rymkiewicza nowy wzorzec paradoksalnego dyskursu, który przyjął postać hermeneutyki istnienia opartej na nierozerwalnym związku "tekstu” i „życia”. Tak mówił o tym poeta:

Ciekawi mnie nie tylko tekst literacki, ale tekst wszelki - tekst życia. Życie pojmuję jako tekst, więc zajmuję się tym, co jest w tekście. [...] Być może nie da się powiedzieć, że jestem historykiem literatury w tradycyjnym sensie. Ale ja się uważam za historyka literatury. Jestem historykiem literatury, jeśli tylko dałoby się powiedzieć, że wszystko jest literaturą, także życie ludzkie ${ }^{23}$.

22 J.M. Rymkiewicz Koniec z imitacjami [rozm. T. Krzemień], „Kultura” 1975 nr 6, s. 6.

23 "Ciekawi mnie tekst życia". Rozmowa z Jarosławem Markiem Rymkiewiczem [rozm. A. Dobrowolski], "Odra" $1987 \mathrm{nr} 1$, s. 18. 
Rymkiewicz podkreśla takie cechy tekstu kultury, jak bezgraniczność, synchronia, intertekstualność i związek z nieświadomością, bliskie formule Jacques'a Derridy „il n'y a pas hors-texte”, ,nie ma nic poza tekstem”" ${ }^{24}$.W efekcie budowana jest biografia tradycji pisarskiej i jej twórców, a jednocześnie autobiografia poety reaktywującego tę tradycję ${ }^{25}$. Chociaż pewne wątki myślowe i rozwiązania formalne są w pisarstwie Rymkiewicza kontynuowane, ulega ono wyraźnej transformacji. Zasadniczą zmianą jest przeniesienie uwagi na „tekst życia”, by poświadczać kruche istnienie konkretnych miejsc czy osób. Teza o językowym zapośredniczeniu rzeczywistości zostaje osłabiona, poeta zaczyna bowiem dopuszczać możliwość powstawania szczelin w kulturowym dyskursie, dzięki którym uobecnia się to, co pozajęzykowe i pozaludzkie. W Żmucie poszukiwanie wiedzy o Połądze, gdzie Adam Mickiewicz prawdopodobnie przebywał z Karoliną Kowalską, dokumentuje intencję, by odkrywać fakty z dziejów, o jakich mało wiadomo, wokół których otwiera się "czarna dziura”, „wodna głębia"26.

Połąga to jest dla nas nazwa pusta i nim zabrałem się do pisania tej książki, też nic o tej miejscowości nie wiedziałem [...].Tuhanowicze są jednym z naszych świętych miejsc, ale ja błagam o litość dla Połągi. Plaże Połągi, Palangi, gdzie zbierał z Karoliną muszle i odłamki bursztynu [...]. Szukałem jakiejś relacji mówiącej o tym, jak wyglądało życie w Połądze lub w Krantz w latach dwudziestych, ale nie udało mi się niczego znaleźć. $(\dot{Z} 117,123)$

Zainteresowanie takimi faktami wynika stąd, że uzmysławiają ułamkowość historii, proces zapominania, a z drugiej strony prowokują akty ożywiania przeszłości. Połąga czy Tuhanowicze to dla Rymkiewicza „miejsca pamięci”,

W komentarzu do pisarstwa Stéphane’a Mallarmégo Derrida stwierdza, że jest ono „zanurzone" w tekstowej "sieci bez końca” (La Dissémination, Editions du Seuil, Paris 1972, s. 253).

Podobne dzieło konstruuje Derrida, który tak mówi o własnym dyskursie, zacierającym gatunkowe i czasowe granice: „może najmniej nieadekwatną nazwą byłaby tu «autobiografia»", odnosząca się do tekstu związanego z „pragnieniem zachowania śladów wszystkich przenikających mnie [...] głosów" (Ta dziwna instytucja zwana literaturq̨. Z Jacques'em Derridq rozmawia Derek Attridge, przeł. M.P. Markowski, w: Dekonstrukcja w badaniach literackich, red. R. Nycz, słowo/obraz terytoria, Gdańsk 2000, s. 18-19). Urzeczenie. Locje literatury i wyobraźni, red. M. Jochemczyk, M. Piotrowiak, Wydawnictwo UŚ, Katowice 2013, s. 307-335. 
jak określa Paul Ricœur swoiste „reminders, wskaźniki przypomnienia”. Umożliwiają one refleksję, dzięki której rzecz z przeszłości, odbierana jako „podwójnie inna: jako nieobecna (inna niż obecna) i jako uprzednia (inna niż teraźniejsza)", okazuje się „ta sama”, z kolei „teraźniejszość zostaje spowita innością tego, co minione"27. Dlatego w tekstach Rymkiewicza biografie form przestrzennych stają się biografiami opisywanych ludzi, a zarazem autobiografią poety, obrazującego własną pracę pamięciową, miejsce i czas, w jakich się ona dokonuje. W tym ujęciu opowiadanie o cudzym i własnym życiu jest praktyką performatywną, jako że polega na interpretacji, kreowaniu i ciągłych zmianach tożsamości. Podobną myśl o literaturze autobiograficznej zawierają późne studia Philippe'a Lejeune'a, nazywającego dziennik „praktyką kulturową" ${ }^{28}$, czy prace Paula de Mana, który uważa autobiografię za „system mediacji" między ja i nie-ja ${ }^{29}$.

„Biografia - pisze Rymkiewicz - to jest zbiór faktów życiowych: rozumowany słownik życia. Ale te fakty życiowe można tak ująć, tak ukształtować, że [...] staną się znakami przeżyć egzystencjalnych" (J 386). W Kilku szczegółach poeta próbuje ustalić, czy Niewiaża była rzeką spławną i czy bliska Mickiewiczowi Łucja Rautenstrauchowa mogła przeprawić się na jej drugą stronę, by poznać tajemnicę życia:

Mamy więc Łucję na promie [...] wsłuchującą się w łomot wody, niejasne przeczucie - że to ma coś wspólnego z życiem lub może z jej przeznaczeniem: rozbryzgujące się strzępy wody, a potem jest ciemnozielona, nieruchoma głębia. [...] Przyglądają się sobie przez chwilę, tylko tyle. On na lewym, a ona na prawym brzegu [...]. Gdzieś w pobliżu pracuje wodny młyn: huk, łomot wody lecącej przez otwarte stawidła. (K 409, 411-412)

Wizję „ciemnozielonej, nieruchomej głębi” objaśniają słowa ilustrujące, na czym polega przekształcanie „faktów życiowych” w „znaki przeżyć egzystencjalnych". Otóż Rymkiewicz tak układa biografię Mickiewicza i Łucji, by powiązać prawdopodobne zdarzenie z fikcją i niejako uczynić je prześwitem, w którym odsłania się istota życia. Epifanię tę łączy poeta z wodą, dającą

P. Ricœur Pamięć, historia, zapomnienie, przeł. J. Margański, Universitas, Kraków 2006, s. 58, 56.

Zob. P. Lejeune Pakt autobiograficzny po dwudziestu pięciu latach, przeł. R. Lubas-Bartoszyńska, W: tegoż Wariacje na temat pewnego paktu..., s. 293. 
wiedzę, że najpierw jest ruch, unaoczniany przez rozbryzgujące się krople, później zaś wszystko zamiera, znika w otchłani; albo inaczej - że w samym ruchu przejawia się pęd ku rozpadowi i znieruchomieniu. Jednostkowe doświadczenie okazuje się więc uniwersalne, w Niewiaży widzieć można Letę i Styks, a w przeprawie promem - podróż na drugi brzeg łodzią Charona.

Opisując formę dziennika, Lejeune wskazuje, iż stanowi on "serię datowanych śladów”, jest „działaniem” tworzącym coś w rodzaju koronki materię, w której więcej pustego miejsca od wypełnień, odniesień znanych tylko autorowi, związanych bowiem z jego własnym doświadczeniem czasu ${ }^{30}$. W dyskursie Rymkiewicza na inskrypcję autobiograficzną składają się, oprócz datowania wierszy, stale powracające nazwy własne i toponimy, a także idiomatyczność wynikająca z podejmowania tych samych wątków w prozie, poezji, dramatach, studiach literaturoznawczych i przekładach. Mediumiczny charakter zawartych w tym dyskursie auto/biografii jest wielowymiarowy, gdyż składają się na niego: pośredniczenie między ja i nie-ja - pisarzami różnych epok, różnymi postaciami samego siebie i członkami rodziny - nawiązywanie bliskiej relacji z czytelnikiem, łączenie odmiennych form twórczości, ponadto zbliżanie ku sobie tego, co ludzkie i pozaludzkie. Wzruszający obraz podtrzymywania więzi znajduje się w wierszu, jaki dziadek podarował wnukowi w prezencie urodzinowym:

Wszedłem - oni siedzieli w słonecznym salonie

Na podjeździe przed dworem wyprzęgano konie [...]

I prapradziadek August drzemał tam w fotelu

Podniósł głowę: - Kim jesteś, młody przyjacielu?

I wyciągnął z kieszonki genewski zegarek

Praprababka szepnęła: - Das ist aber Jarek! [...]

Z życia nie było wyjścia - jak z zajęczej matni

Wszedłem i powiedziałem: - Nie jestem ostatni

(Wiersz dla Ignacego Rymkiewicza (na jego pierwsze urodziny), P 20-21).

30 P. Lejune Koronka. Dziennik jako seria datowanych śladów, przeł. M. i P. Rodakowie, „Pamiętnik Literacki" 2006 z. 4, s. 23. Zob. ponadto tegoż Autobiografia i poezja (fragmenty), przeł. R. Lubas-Bartoszyńska, w: tegoż Wariacje na temat pewnego paktu..., s. 299-304. 


\section{Abstract}

\section{Dorota Wojda}

JAGIELLONIAN UNIVERSITY (CRACOW)

Rymkiewicz's Telescope: Mediumistic Auto/Biographies of Modern Classicism

Wojda explores Jarosław Marek Rymkiewicz's biographies and autobiographies as presented in his prose, poetry, drama, translations and literary studies. Based on the hermeneutical principle that writing about others is also writing about oneself, Rymkiewicz's (auto)biographies blend into one single discourse, and the metaphor of the telescope corresponds to the mediumship of this discourse. In the poet's modern classicism, this mediumship is related to the formula of imitation as an intermediary between texts and persons - an intermediary in which equal weight is given to similarities and differences, closeness and distance. Reading Rymkiewicz's works, especially the poem Exegi monumentum from the collection Thema regium (1978), Wojda draws attention to the paradoxical practice of combining mimeticism with fiction, bodily empiricism with the role of signs, cognition with creation. Assuming a diachronic perspective, Wojda shows that Rymkiewicz's cultural hermeneutics transitioned into a micro-historical hermeneutics of existence, "the text of life".

\section{Keywords}

Jarosław Marek Rymkiewicz, biography, mediumship, modern classicism 